\title{
Vacuum conveyor belts perforation - methods, materials and problems
}

\author{
Perforacja pasów do transportu podciśnieniowego \\ - metody, materiały oraz problemy
}

\author{
DOMINIK WOJTKOWIAK \\ KRZYSZTOF TALAŚKA \\ IRENEUSZ MALUJDA \\ GRZEGORZ DOMEK *
}

The analysis of suitable perforation methods for polymer composites belts with regard to modern material trends in manufacturing the conveyor and timing belts for the vacuum transport was presented. Authors also discussed problems, which occurs during belt perforation and specified the research area, which will help to develop the production process of perforated belts.

KEYWORDS: vacuum belts, perforation, methods, belt conveyors, conveyor, timing belts, polymer composites belts

Vacuum belt conveyors are often used to transport lightweight elements, which due to their low weight cannot be transferred by means of friction (e.g. paper, foil or cardboard), and for transporting sheets [1]. They are therefore widely used, among others, in the paper, food and chemical industries, as well as in printing machines and general handling equipment. Vacuum belts can be in the form of both flat and toothed belts. The most important process in the production of such belts is perforation - i.e. making holes, through which air is sucked out to create a vacuum between the belt and the transported element.

The authors analyzed available methods of perforation, taking into account contemporary trends in the development of materials used for the production of composite belts, and pointed to the problems associated with the perforation of belts and belt conveyors.

\section{Conveyor tapes and belts}

The conveyor tape is used to support the transported material and carry it along the conveyor. Its tasks also include the transmission of longitudinal forces, which are necessary to overcome the resistance of motion, in the case when the conveyor does not have a separate thrust rod. The tape conveyor can transport bulk, small or large individual items on the surface of one tape. To function properly, conveyor tapes should have high tensile strength and be elastic in both the longitudinal and transverse direction, as well as durable, resistant to

\footnotetext{
Mgr inż. Dominik Wojtkowiak (dominik.wojtkowiak@put.poznan.pl), dr inż. Krzysztof Talaśka (krzysztof.talaska@put.poznan.pl), dr hab. inż. Ireneusz Malujda prof. PP (ireneusz.malujda@put.poznan.pl) - Katedra Podstaw Konstrukcji Maszyn Politechniki Poznańskiej; dr hab. inż. Grzegorz Domek prof. nadzw. (gdomek@ukw.edu.pl) - Uniwersytet Kazimierza Wielkiego w Bydgoszczy
}

DOI: https://doi.org/10.17814/mechanik.2017.12.192

abrasion, punctures, mechanical and external factors and have high friction coefficient of the support cover [2, 3].

Conveyor belts - unlike conveyor tapes - perform transport and drive functions. They are used for multidirectional, linear or angular movement of the load. The conveyor belts can transport single products of considerable dimensions and relatively small mass. The transport takes place by means of several belts driven by a common drive shaft - to ensure an even speed of the conveyor elements.

Their unquestionable advantage is the ability to access the transported goods from below. Structure can be flat, wedge or cogged. Conveyor belts should, above all, have high tensile strength and at the same time rigid enough to ensure stability during transport, while allowing the belt to wrap around a small diameter drive shaft. In the case of the need for precise positioning (motion synchronization), toothed belts [4-6] are used.

The growing requirements as to the properties of belts and tapes used as construction elements in modern machines and devices are a necessity of their continuous improvement in the scope of construction, materials and related to the production technology [7].

Both conveyor tapes and flat and cog conveyor belts can be used for vacuum transport. Flat belts usually have the structure of a multilayer polymer composite (fig. 1) and consist of core 1, protective spacers 2 and covers: running 3 and carrier $4[2,3]$.

Among the flat belts available on the market, following can be distinguished:

- elastic light belts, the core of which is made of polyurethane, sometimes reinforced with polyester fabric, polyvinyl chloride (PVC), fabric or rubber - LA-15E20,

- rigid belts with increased strength, the core of which is a layer of polyamide - TFL10SEH,

- durable, flexible belts, the polyurethane core of which is reinforced with aramid fiber (kevlar) cord - CFTG-40F.

In most belts - due to the favorable friction properties the running and carrying cover is made of butadieneacryl-nitrile rubber (NBR), which may have different surface structure. In order to obtain a non-flammable and smooth structure on the covers, PVC is also often used. Protective pads are mainly found in strong belts and are designed to protect the core and additionally reinforce the belt. The most common role of the spacer is a layer of properly woven polyamide fabric, often embedded in the core structure. Fig. 1 shows the Nitta belts from the three groups described, which are characterized by the most common structure. 


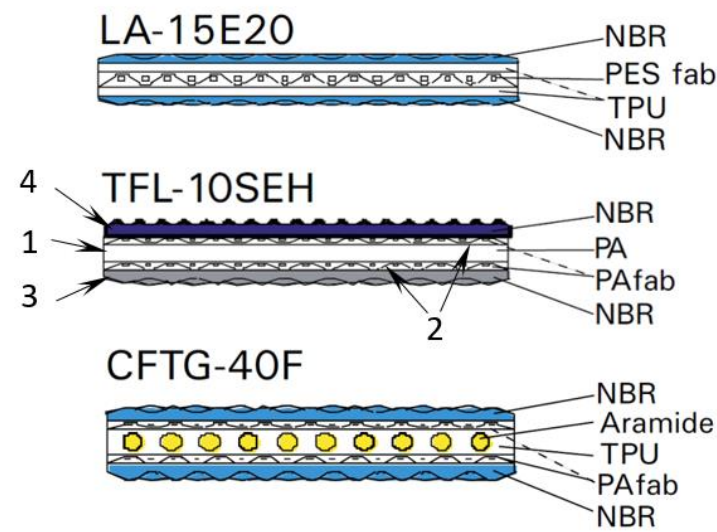

Fig. 1. Structure and materials of composite conveyor belts: LA15E20 - elastic polyurethane reinforced polyester laminate, TFL-10SEH - strong, rigid polyamide core, CFTG-40F - strong elastic polyurethane belt reinforced with fiber aramid; NBR butadiene-acryl-nitrile rubber, TPU - polyurethane, PA polyamide, PES - polyester, fab - fabric, Aramide - kevlar (description in the text) [20]

Toothed belts (fig. 2) are usually made of rubber or polyurethane, which are a matrix, and a steel cord or aramid or glass fibers, which create the tension member that provide reinforcement. In order to obtain special properties of the belt, e.g. to reduce friction or to provide quieter operation, both sides of the belt can be covered with a suitable coating (from polyurethane foam, nylon fabric, etc.).

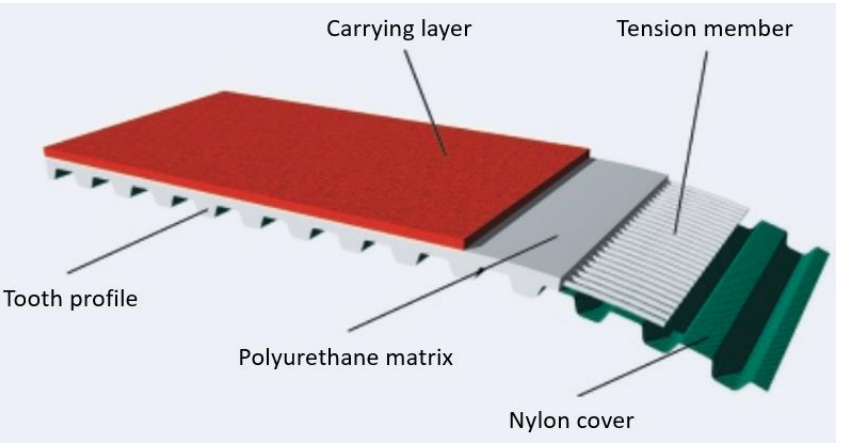

Fig. 2. Structure of a polyurethane toothed belt reinforced with cord and covered with coatings on the carrying and running side [21]

To meet the growing requirements for conveyor belts, numerous modifications are made. Fig. 3 shows examples of Habasit toothed belts.

Toothed belts often have a milled part of the teeth, which allows them to be guided properly, allows additional mechanical elements to be mounted, or provides a flat raceway to create a suitable underpressure. By milling, grooves are also made, which are used to increase the contact surface area during vacuum transport between the belt and the conveyed element. In turn, to obtain the appropriate properties of the belt covers, new layers are applied or existing ones are formed, e.g. by cutting. The last and, at the same time, the most important modification in the aspect of vacuum transport is perforation.

In addition to vacuum transport, perforated belts can be used for optical control using photocells, fixing mechanical elements on the belt, draining and drying of transported elements, their segregation or positioning.

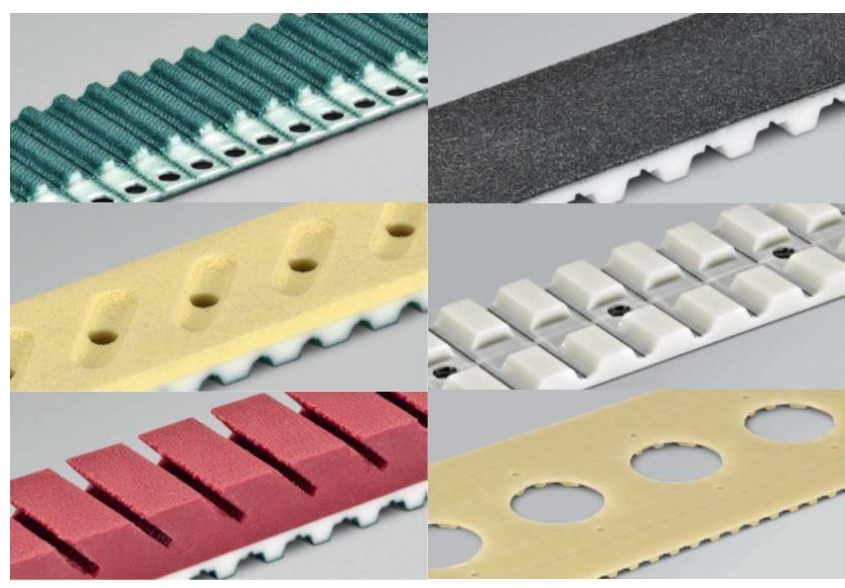

Fig. 3. Examples of modification of toothed belts by Habasit [22]

\section{Methods of composite belts perforation}

The quality of the holes in the perforated belt is important for its properties, therefore it is so important to choose the right method of perforation and its parameters. Mechanical methods of belt perforation, including punching and drilling, as well as nonmechanical methods, such as: laser cutting, abrasive waterjet (AWJ), plasma cutting and EDM (electrodischarging) can be distinguished.

Non-mechanical perforation has the advantage over mechanical perforation, because it is not accompanied by contact forces between the tool and the workpiece. Thus, there is no deformation of the element due to mechanical load or friction wear of the tool. This method, however, is much more expensive due to investment and operating costs. Because polymers are electrical insulators, it is impossible to use plasma or EDM cutting [8]. In order to determine, which of the perforation methods is best suited for composite strips, other methods have been briefly characterized.

Laser treatment of polymers can be carried out in two ways: by breaking molecular bonds with laser radiation or by melting the material and evaporating it in a mixture of shielding gases. Due to the properties of polymers, it is recommended to use a gaseous $\mathrm{CO}_{2}$ laser generator, the highly coherent laser beam of which can be continuous (continuous wave) or pulsed.

Because the cutting process is of a thermal nature, the hardness and strength of the workpiece do not affect its course. However, the efficiency of the process decreases significantly as the thickness of the belt increases. High temperature during laser treatment leads to changes in material properties in the heat affected zone (HAZ) and thermal deformation of the element (charring, damming the matrix material around the edge of the hole or delaminating). Providing the right ratio of laser power and cutting speed allows to reduce HAZ and reduce hole defects. It is recommended to use a higher speed, because it shortens the time, during which the composite is heated, but at the same time leads to less penetration of the laser into the material. In fiberreinforced composites, the fibers are often swollen, the thermal shrinkage of the matrix and the burning of the uncut fibers can occur.

The greater the difference between matrix and reinforcement properties, the cutting process is less effective. For aramid fibers and polyurethane, these differences are small, but during the Kevlar laser 
treatment, charring occurs and large amounts of toxic hydrogen cyanide are released. Due to the anisotropy of the properties of such belts, the cut perpendicular to the fibers causes the HAZ to increase as compared to cutting along the fibers. When punching cylindrical holes with smaller diameters, laser drilling can be used, in which the direction of fibers is not important, however, with larger holes and the need for laser cutting, it will introduce diversity in the temperature distribution in the HAZ zone. In terms of cut-hole geometry, the use of laser cutting allows for high shape accuracy due to the narrow cutting gap and a fairly good quality of the side surface of the hole. Due to the conical shape of the laser beam, diameters on both sides of the belt may slightly differ [8-11].

Cutting with a water-abrasive jet involves the erosion of the material under the influence of a narrow stream under very high pressure, formed in a special nozzle, so that it reaches sufficient power to process even the hardest materials. The AWJ method is universal - it can be used for most materials, from very thin to thick. Its most important advantage is the lack of thermal interactions on the processed material, therefore it is ideally suited for processing plastics.

Due to the greater width of the cutting gap than for laser processing, cutting precision is less, but still sufficient, even when the shapes are complicated. The quality of the machined surfaces is much better and depends mainly on the size of the abrasive grains and its mass output. In materials with significant thicknesses, characteristic curved machining marks appear depending on the feedrate.

AWJ cutting is much slower than laser cutting, but it is environmentally friendly due to the lack of release of harmful substances and the possibility of recycling the medium. The erosive nature of the process allows the application of this method to multi-layer composites delamination occurs only at very high speeds or when the material is sensitive to moisture. In the case of AWJ perforations, the greatest influence on roundness deviation has the speed of the cutting head - an increase in velocity causes almost linear increase of the deviation. The other process parameters - such as distance of the head from the workpiece and the mass flow of abrasives - have much smaller impact on the roundness deviation of the holes. In the case of composites reinforced with aramid fibers, the uncut fibers may be frayed $[8,11,12]$. An additional disadvantage may be the need to dry the strips after perforation.

Drilling involves making cylindrical holes by machining a material with a high-speed drill bit. It is one of the most commonly used methods of making mounting holes in composite materials. Incorrect selection of the operating parameters or cutting tool leads to numerous damage. A classic twist drill bit is not suitable for processing composites, therefore it is necessary to use special effective tools (fig. 4). Constructions (a) and (c) cause the least delamination due to the reduction of the length of the drill cut, while the drill bit (b) minimizes the undercutting of the protruding fibers. For drilling in thin laminates, tools like type (a) are recommended.
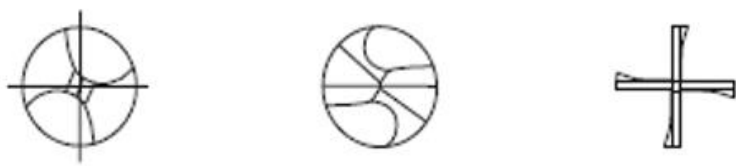

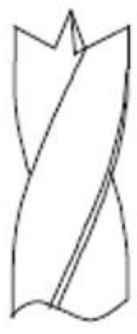

(a)

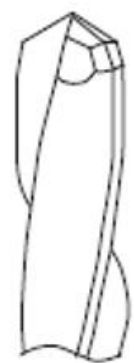

(b)

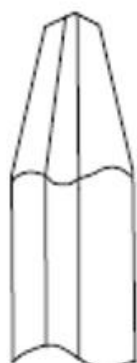

(c)
Fig. 4. Structures of effective cutting tools for drilling in layered and fiber-reinforced composites (description in the text) [8]

During drilling, a significant amount of heat associated with friction is released, which increases with the cutting speed and feedrate. Therefore, the composites are drilled only in a narrow range of technological parameters to prevent excessive heating of the workpiece and to compensate for the thermal deformation of the composite. In addition, the poor thermal conductivity of polymer composites causes heat concentration at the drilling site and the necessity of draining it through the drill, which significantly shortens the life of the tool. Differentiation of the properties of the composite components makes it difficult to obtain dimensional accuracy - there is a shrinkage of the material after its cooling. Reinforcing fibers significantly accelerate the wear of the cutting edges, which leads to an increase in the axial force, thus increasing the risk of delamination.

Delamination of the composite during drilling may take place from the drill's entry and exit side. In the first case, it is the result of stripping off the top cutting layers and wrapping the fibers around the drill. On the other hand, in the second case, it is caused by pressing out the lower layers due to exceeding the limit of cohesion, by additional bending and compressive stresses. The strategy of preventing delamination is to increase the rigidity of the lower layer due to the use of a support plate or variable working feed. Another defect of drilling in composites may be the ovality of openings related to the orientation of fibers in the material structure [8, 1315].

Punching consists in the mechanical cutting of the hole as a result of stress on the shear surfaces necessary to overcome the cohesion of the material. The cutting work is performed by a rigid tool which, by moving, presses against the shaped material. The punching process can be carried out with one or two cutting edges, constituting a closed contour. In the first case, the cutting edge is a sharpened punch cooperating with the underlay plate, whereas in the case of two cutting edges, a cylindrical punch cooperating with the punching die is most often used $[16,17]$. The basic tools used for mechanical belt punching are shown in fig. 5 . 


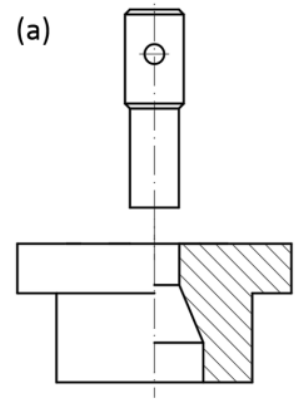

(b)

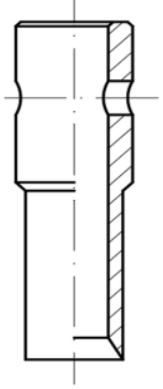

(c)

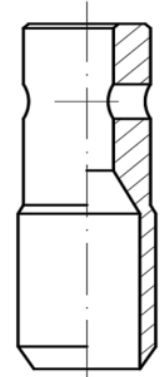

Fig. 5. Constructions of popular punching tools for belt perforation: a) full cylindrical piercing punch with a die, b) hollow cylindrical piercing punch with a blade directed inwards, c) hollow cylindrical piercing punch with a blade pointing outwards

In comparison to drilling holes, the punching process is much faster, and with a suitable punch design, many holes can be made simultaneously (e.g. whole patterns). Another advantage is the possibility of obtaining holes in any shape. The most important feature that makes the punching process ideally suited for the perforation of composite belts is the lack of heating of the workpiece or tool during machining, therefore the tool wear is much slower than during drilling and there is no thermal deformation or change in the mechanical properties of the belt. The simple kinematics of the process facilitates its automation, and the cost of machining depends only on the cost of the die. Of course, punching holes are not free from defects and the right selection of tools and process parameters is crucial here [15-19].

\section{Problems with perforating conveyor belts and tapes by punching}

There are few publications and scientific studies on the cutting of composite materials [18, 19], while the process of punching metals and their alloys is widely and accurately described. Guidelines on both the design of blanking dies and the choice of process parameters can be found in literature, due to which this type of plastic processing is popular in the production of metal elements $[16,17]$. Lack of systematized guidelines for other material groups significantly extends the process design time and the construction of effective tools. This is the main reason for the rare use of punching for composites. Contrary to appearances, this process is very complex, and the quality of the holes made and the value of the perforation force is influenced by many parameters: tool geometry, clearance between piercing punch and die, punch speed and temperature, thickness and type of the workpiece, tool wear, friction and pressure cut material [15-19].There is a lack of research on the perforation of composite belts and tapes in the literature, which is the source of technical and construction problems for Polish and worldwide belt manufacturers.

On the basis of literature analysis, contacts with companies involved in the production of belts and own research experience, the basic problems of belt perforation were defined by punching. In the case of flexible belts and tapes, large elastic deformations occur during punching, which may cause distortion of the contour of the hole or - with too much tension permanent deformation of the belt. In addition, the orthotropic properties of composite tapes, ensuring greater susceptibility in longitudinal than transverse direction of the belt, often cause the ovality of the openings. This is of little importance for vacuum transport, but it can cause problems with the mounting holes.

Fabrics - often used in belts with a sandwich construction as protective liners or covers - may be undressed or frayed. The same applies to belts reinforced with fibers (cord), which are not cut and extend beyond the outline of the hole. Such fibers can damage delicate goods on the conveyor or have undesirable contact, e.g. with transported food. To prevent this, many manufacturers recommend the perforation of belts in places, where there is no reinforcement [6, 15-19]. The problem is aramid fibers, which increase the wear of the cutting tool and require its very high hardness. Perforation of conveyor belts with a polyamide core is also problematic due to the necessity of applying a high perforation force and due to differences between the diameters of holes on both sides of the belt (conical form of holes). All these defects can be overcome or eliminated by the appropriate selection of process parameters and through the use of effective tool geometry.

\section{Conclusions}

Analysis of the perforation process, taking into account contemporary trends in the development of materials used for the production of conveyor belts and tapes, clearly indicates the need for the development of punching composites as a method of precise mechanical perforation of vacuum conveyor belts. A series of tests is planned for this purpose, the main purpose of which is to develop a model for the perforation of composite belts and conveyor tapes. The results of these tests will enable the design of the effective geometry of the perforating tool and determination of effective parameters of the punching process for belts with a polyamide core and belts reinforced with aramid fibers.

The main research will include multi-parametric analysis of the effect of process parameters - such as: tool geometry (e.g. angle and direction of blade inclination, diameter, wall thickness), nature of the punch interaction with either die or the backing plate (its mechanical properties), type and method of fixing the workpiece (thickness, structure and composite materials as well as belt pressure), punch speed, tool quality (wear rate, material and hardness), and even punch temperature - on the perforation force, hole quality and tool durability.

Preliminary tests have shown that appropriately carried out deliberately increasing the temperature of the punch has a positive effect on the quality of the hole and can be crucial, for example, in the case of perforation belts with a polyamide core. Hence, the study of the influence of temperature on the perforation process is considered important. The complementation of the tests also consists of investigations of mechanical properties of the discussed groups of belts in order to develop material models necessary in the FEM analysis, which will be the essence of the scientific work. At further stages, it is planned to extend the research with the remaining groups of conveyor belts and tapes.

\section{REFERENCES}

1. Perneder R., Osborne I. „Handbook Timing Belts - Principles, Calculations, Applications". Berlin: Springer, 2012. 
2. Hardygóra M. "Taśmy przenośnikowe", rozdz. 1 i 2. Warszawa: Wydawnictwo Naukowo-Techniczne, 1999.

3. Gładyszewicz L. „Przenośniki taśmowe - teoria i obliczenia”. Wrocław: Wydawnictwo Politechniki Wrocławskiej, 2003

4. Dudziak M. „Przekładnie cięgnowe”. Warszawa: PWN, 1997.

5. Domek G. "Tendencje projektowania pasów zębatych". Zeszyty Naukowe Politechniki Śląskiej. Transport.82, nr kol. 1903 (2014): pages 59-66.

6. Optibelt. „Technical manual polyurethane timing belts - katalog". www.optibelt-usa.com (data dostępu: 06.07.2017).

7. Krawiec P., Domek G. „Nowe perspektywy stosowania przekładni z pasem zębatym w technice sterowania i napędu". Technologia i Automatyzacja Montażu. 4 (2007): pages 15-19.

8. Sheikh-Ahmad J. „Machining of polymer composites”. Springer, 2009.

9. Chryssolouris G., Salonitis K. "Fundamentals of laser machining of composites". Machining Technology for Composite Materials. R. 10 (2011): pages 266-287.

10. Negarestani R., Li L. "Laser machining of fibre-reinforced polymeric composite materials". Machining Technology for Composite Materials. 11 (2011): s. 288-308.

11. Krajcarz D. "Comparison Metal Water Jet Cutting with Laser and Plasma Cutting". Procedia Engineering. 69 (2014): pages 838-843.

12. Krajcarz D., Spadło S. "Wpływ wybranych parametrów procesu cięcia strugą wodno-ścierną na odchyłkę okrągłości otworów cylindrycznych". Mechanik. 1 (2017): pages 64-65.

13. Lachaud F., Piquet R., Collombet F., Surcin L. „Drilling of composite structures”. Composite Structures. 52 (2001):

pages 511-516.

14. Leppert T., Paczkowski T., Polasik R., Serwacki D. „Delaminacja materiału kompozytowego włóknistego podczas wykonywania otworów". Mechanik. 10 (2016): pages 1422-1423.

15. Lambiase F., Durante M. „Mechanical behavior of punched holes produced on thin glass fiber reinforced plastic laminates". Composite Structures. 173 (2017): pages 25-34.

16. Suchy I. „Handbook of Die Design”. McGraw-Hill Companies, 2006.

17. Marciniak Z., „Konstrukcja tłoczników”. Ośrodek Techniczny Marciniak, 2002.

18. Chan H.Y., Abdullah A.B., Samad Z. "Precision punching of hole on composite panels". Indian Journal of Engineering \& Material Sciences. 22 (2015): pages 641-651.

19. Zain M.S.M., Abdullah A.B., Samad Z. "Effect of puncher profile on the precision of punched holes on composite panels". International Journal of Advanced Manufacturing Technology. 89 (2017): pages 3331-3336.

20. Katalog produktów Nitta PolyBelt ${ }^{\circledR}$ i PolySprint ${ }^{\circledR}$ firmy Wilhelm Herm. Müller.

21. Katalog pasów zębatych Brecoflex ${ }^{\circledR}$ firmy Breco.

22. Katalog produktów HabaSYNC $®$ firmy Habasit. 